\title{
Molecular Detection of Zonula Occludens Toxin (zot) Genes in Vibrio Cholerae O1 using PCR
}

\author{
Seyedeh Mahnaz Mousavi, Mehdi Zeinoddini *, Azadeh Azizi, AliReza Saeedinia, Arina Monazah \\ Department of Bioscience and Biotechnology, Malek Ashtar University of Technology, Tehran, Iran.
}

\author{
Received: 27 Jul 2017 \\ Revised : 19 Aug 2017 \\ Accepted: 7 Sep 2017 \\ Corresponding Author: \\ Mehdi Zeinoddini \\ Department of Bioscience and \\ Biotechnology, Malek Ashtar \\ University of Technology, Tehran, \\ Iran. \\ Phone: +98-9122148110 \\ E-mail: zeinoddini52@mut.ac.ir
}

\begin{abstract}
Background: Zot (Zonula occludens toxin) is one of the secretion toxins of Vibrio cholerae in small intestine that binds to certain receptors in the epithelial cells and causes a change in the structure of tight junction. The purpose of this research is rapid detection of zot enterotoxin gene using PCR.

Materials and Methods: The genomic DNA was extracted by DNA isolation kit and gene amplification was carried out by the zot gene-specific primers. Then, PCR products were investigated by electrophoresis on $1.2 \%$ agarose gel stained by ethidium bromide. Also, the specificity of primers was measured using bacterial samples other than V. cholerae, such as enterotoxigenic Escherichia coli (ETEC), Salmonela. typhi and Aeromonas hydrophila. The sensitivity of the PCR reaction was also evaluated using serial dilutions of $V$. cholerae $\mathrm{O} 1$ concentration (cfu/ml).

Results: The data showed that the designed primers specificity for zot gene was successful and the sensitivity of this method was determined about $142 \mathrm{cfu} / \mathrm{ml}$.

Conclusion: In conclusion, this molecular detection can be used as a simple diagnostic kit in clinical laboratories for identification of $V$. cholerae.
\end{abstract}

Keywords: Vibrio cholera; zot; PCR; diagnosis

Please cite this article as: Mousavi SM, Zeinoddini M, Azizi A, Saeedinia A, Monazah A. Molecular detection of zonula occludens toxin (zot) genes in Vibrio cholerae O1 using PCR. Res Mol Med, 2017; 5(3): 37-40

\section{Introduction}

Vibrio cholerae, the causative agent of cholera, is an important agent for causing severe diarrheal disease in many parts of the world. According to severe watery diarrhea and rapid dehydration, this disease may lead to death of the patients $(1,2)$. Cholera is a seasonal disease and occurs especially in the warm seasons of the year in areas where poor health is present (3). Therefore, correct, reliable and rapid detection of cholera toxin (CT)-producing $V$. cholerae is very important. Today, many identification methods are carried out for detection of $V$. cholerae such as conventional culture, biochemical, immunological and molecular-based assays (4-7). Although isolation and identification of $V$. cholerae by culture of a stool specimen is the gold standard for the laboratory detection of cholera, this method is time consuming and laborious, requiring more than three days (8). On the other hand, this method and some commercially available kits cannot distinguish between $\mathrm{CT}$ and the heat-labile enterotoxin (LT) of Escherichia coli (9). Also, due to nutrient starvation and physical stress, this bacterium may enter a viable but non-culturable
(VBNC) state. Therefore, this procedure may explain the failure of traditional culture methods for isolation and detection of this infectious agent from contaminated water and food samples implicated in foodborne outbreaks $(10,11)$. In this field, molecular diagnosis can be a key strategy and is used for successful detection of this infectious agent. Zonula occludens toxin (zot), is a main toxin from $V$. cholerae that regulates tight junction permeability, reversibly. Since the location of the zot coding gene is upstream of cholera toxin, zot can play a synergistic role in the development of symptoms $(12,13)$. In this work, we used PCR for identification of zot enterotoxin gene in order to develop a rapid and correct detection kit.

\section{Materials and methods \\ DNA Extraction}

$V$. cholerae (O1 serogroup), enterotoxigenic Escherichia coli) ETEC (Salmonela Typhi and Aeromonas hydrophila were obtained from Bou-Ali Hospital in Tehran. All Strains were grown for $24 \mathrm{~h}$ in LB broth, aerobically. Then, the bacterial 
sedimentation was done by centrifugation at $9000 \mathrm{~g}$ for 5 minutes and finally, genomic DNA was purified using a DNA extraction kit (DNP TM Kit, SinaClon BioScience) according to manufacturer's protocol.

\section{Primer design}

In this study, zot gene sequence was examined in GenBank and primers were designed according to this sequence. For this, one pair of primers was designed for specific amplification of this gene (Forward: 5'-CGGCTTTGTGTCCAAGATGG-3' and reverse: 5'-CGCTGCAAAGGTATCGAACA-3'). Accordingly, a specific band of 246 bp was amplified.

\section{PCR Reaction}

PCR was performed with forward and reverse primers, the final volume for each reaction was $5 \mu \mathrm{l}$, which included $60 \mathrm{ng}(1 \mu \mathrm{l})$ of DNA template, $2.5 \mu \mathrm{M}$ $(0.25 \mu \mathrm{l})$ each of the forward and reverse primers, 2.5 $\mu 1$ master mix of Taq DNA polymerase (Ampliqon PCR Kit, Denmark) and $1 \mu$ of distilled water. The program of thermocycler for reaction was prepared: initial denaturation at $94{ }^{\circ} \mathrm{C}$ for 5 minutes and 30 cycles including denaturation $\left(95^{\circ} \mathrm{C}, 1 \mathrm{~min}\right)$, annealing $\left(55^{\circ} \mathrm{C}, 1 \mathrm{~min}\right)$, extension $\left(72{ }^{\circ} \mathrm{C}, 1 \mathrm{~min}\right)$ and final extension at $72{ }^{\circ} \mathrm{C}$ for 5 minutes. After completion of the reaction, $\mathrm{PCR}$ products were examined using $1.2 \%$ agarose gel electrophoresis.

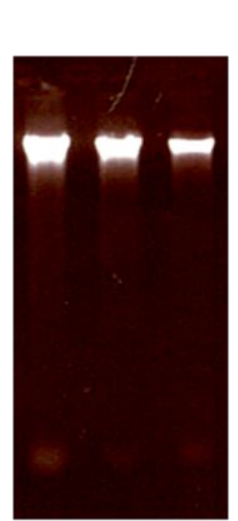

A

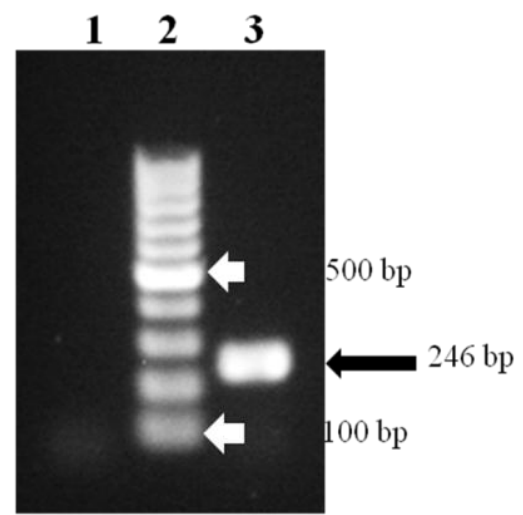

B
Figure 1. Agarose gel electrophoresis for extracted genomic DNA (A) and PCR products (B). Negative control (1), 100-bp ladder (2), PCR product (3).

Specificity and sensitivity of primers

To evaluate the specificity of the designed primers, genomic DNA samples were selected as DNA templates from $V$. cholerae O1 (Inaba Serotyping), ETEC (enterotoxigenic Escherichia coli), Salmonela. typhi and Aeromonas. hydrophila were selected as DNA templates. Moreover, to determine the sensitivity of the test, a sample of $V$. cholerae was diluted sequentially from $1.42 \times 10^{7} \mathrm{cfu} / \mathrm{ml}$ to $1.42 \times 10$
- $4 \mathrm{cfu} / \mathrm{ml}$, and PCR was performed with each of these dilutions. Finally, PCR products were examined with $1.2 \%$ agarose gel electrophoresis.

\section{Results}

PCR Detection

The extracted DNA from $V$. cholerae culture was evaluated using electrophoresis on $1.2 \%$ agarose gel (Figure 1A). The measured DNA value with NanoDrop instrument was $62 \mathrm{ng} / \mu \mathrm{l}$. To carry out the PCR reaction, extracted DNA was used as template. PCR reaction was done. After amplification and analysis with $1.2 \%$ agarose gel, a clear band was observed at position $246 \mathrm{bp}$, which confirmed presence of zot gene in the $V$. cholerae sample (Figure1B).

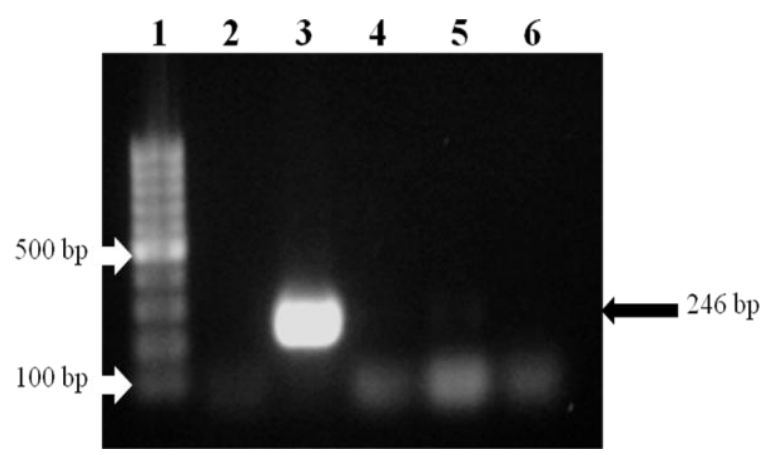

Figure 2. Specificity of designed primers for PCR reaction. 100-bp ladder (1), negative control (2), V.cholerae (3), ETEC (4), Salmonela typhi (5), Aeromonas hydrophila (6).

Specificity and sensitivity of primers in PCR detection

To confirm the specificity of primers, DNA templates were selected from samples of $V$. cholerae, ETEC (enterotoxigenic Escherichia coli), Salmonela typhi and Aeromonas hydrophila.

\section{3}

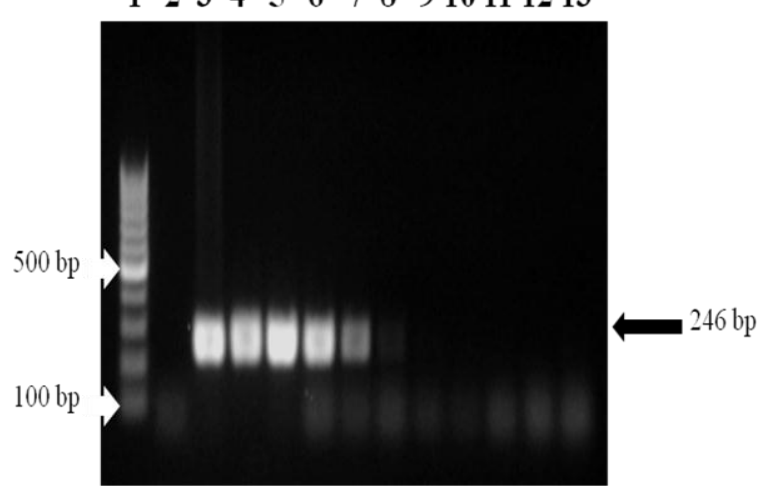

Figure 3. Sensitivity of PCR obtained using different dilutions of the $V$. cholerae genome based on copy number (cfu/ml). 100-bp ladder (1), negative control (2), $1.4210^{7}(3), 1.4210^{6}(4), 1.4210^{5}$ (5), $1.4210^{4}(6), 1.4210^{3}(7), 1.4210^{2}(8), 1.4210^{1}(9), 1.4210^{-1}$

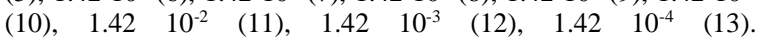


The electrophoresis on the agarose gel showed a clear band for $V$. cholerae at $246 \mathrm{bp}$, confirming the specificity of primers designed for zot gene in $V$. cholerae. In samples other than Vibrio, which were used as a template, they were not amplified and were observed as primer dimers (Figure 2).

To confirm the PCR sensitivity, serial dilutions were prepared from $1.42 \times 10^{7} \mathrm{cfu} / \mathrm{ml}$ to $1.42 \times 10^{-4} \mathrm{cfu} / \mathrm{ml}$ of $V$. cholerae genome and considered as a template for the reaction. After analysis of PCR products, it was found that the sensitivity of this assay is about 142 $\mathrm{cfu} / \mathrm{ml}$ (Figure 3).

\section{Discussion}

In this work, we developed a simple diagnostic molecular assay for detection of zot gene from $V$. cholera. For this, the specificity of primers was studied using bacterial samples other than V.chlorae including enterotoxicogenic E. coli, Salmonella typhi and Aeromonas hydrophila, which data showed that the specificity of primers for $V$. cholerae is successful. In addition, the sensitivity of the PCR technique was investigated by providing different dilutions of the $V$. cholerae genome, and the limit of detection was determined about $142 \mathrm{cfu} / \mathrm{ml}$.

Conventional microbiological methods for detection of $V$. cholerae are time consuming and expensive. Molecular assays such as PCR are very specific compared to conventional methods and suitable alternative to traditional methods $(14,15)$. The rapid diagnosis of cholera and its timely treatment is very important (16). Cholera is one of the infectious and acute diseases of the gastrointestinal tract that is associated with reduced water and electrolyte imbalances in the patient's body (17). Toxigenic strains of $V$. cholerae have played an important role in the development of cholera epidemics (18). zot is the second toxin of $V$. cholerae, which increases the permeability of bowel intestinal mucosa by altering the zonula occludens joints $(19,20)$. The change caused by zot enterotoxin is reversible and limited to the small intestine (21). In the present work, by designing specific primers for the zot gene, a PCR technique was used to amplify this gene. In 2011, Chua et al., used a triplex PCR method to identify toxic and non-toxigenic $V$. cholerae. The diagnostic limit of this method was reported $2 \times 10^{4}$ cfu (3). In 2012, Mehrabadi et al., used the multiplex PCR method to identify toxigenic $V$. cholerae, which had a diagnostic limit of 10-100 cfu (15). In 2014, Barzamini et al, used a PCR method to detect ctxA gene and their diagnostic limit was estimated about $40 \mathrm{cfu} / \mathrm{ml}$ (14). In 2015, Zeinoddini et al, with new method, triplex dot blotting assay, detected $V$. cholerae in sensitivity of $10 \mathrm{cfu}$ (6).

\section{Conclusion}

In conclusion, according to this molecular detection we could develop a simple diagnostic kit for clinical laboratories in order to identify $V$. cholerae.

\section{Acknowledgements}

The authors would like to thank the research council of Malek Ashtar University of Technology (MUT) for the financial support of this investigation.

\section{Author Contributions}

The authors have similar contributions.

\section{Conflict of Interest}

The authors declare no conflict of interest.

\section{References}

1. Faruque SM, Albert MJ, Mekalanos JJ. Epidemiology, genetics, and ecology of toxigenic Vibrio cholerae. Microbiol Mol Biol Rev. 1998; 62(4):1301-14. PMID: 9841673

2. Vivian Joseph Ratnam P, Sundararaj T, Rajkumar S. Genotyping of Vibrio cholerae strains based on the cholera toxin and virulence associated genes. Med Sci. 2015; 5(7): 197-99.

3. Chua AL, Elina HT, Lim BH, Yean CY, Ravichandran M, Lalitha P. Development of a dry reagent-based triplex PCR for the detection of toxigenic and non-toxigenic Vibrio cholerae. J Med Microbiol. 2011; 60(4):481-5. PMID: 21183596

4. Brumfield KD, Carignan BM, Ray JN, Jumpre PE, Son MS. Laboratory techniques used to maintain and differentiate biotypes of Vibrio cholerae clinical and environmental isolates. J Vis Exp. 2017; 30(123):e55760. PMID: 28605374

5. Israil A, Balotescu C, Damian M, Dinu C, Bucurenci N. Comparative study of different methods for detection of toxic and other enzymatic factors in Vibrio cholerae strains. Roum Arch Microbiol Immunol. 2004; 63(1-2):63-77. PMID: 16295321

6. Zeinoddini M, Saeedinia AR, Sadeghi V, Shamsara M, Hajia M, Rahbar M. Simple and accurate detection of Vibrio cholera using triplex dot blotting assay. Biomacromol J. 2015; 1(1):52-7.

7. Zeinoddini M, Saeedinia AR, Sadeghi V. Rapid detection of Vibrio cholera using hexaplex PCR assay. Police Med. 2014; 3(2): 77-84.

8. Kaper JB, Morris JG, Lerine MM, Cholera. Clin Microbiol Rev. $1995 ; 8$ (1) 48-86.

9. Yamazaki W, Seto K, Taguchi M, Ishibashi M, Inoue K. Sensitive and rapid detection of cholera toxin-producing Vibrio cholerae using a loop-mediated isothermal amplification. BMC Microbiol. 2008; 8(1):94.

10. Alam M, Sultana M, Nair GB, Siddique AK, Hasan NA, et al. Viable but nonculturable Vibrio cholerae $\mathrm{O} 1$ in biofilms in the aquatic environment and their role in cholera transmission. Proc Natl Acad Sci U S A. 2007; 104(45):17801-6. PMID: 17968017

11. Aulet O, Silva C, Fraga SG, Pichel M, Cangemi R, Gaudioso $\mathrm{C}$, et al. Detection of viable and viable nonculturable Vibrio cholerae $\mathrm{O} 1$ through cultures and immunofluorescence in the Tucumán rivers, Argentina. Rev Soc Bras Med Trop. 2007; 40(4):385-90. PMID: 17876456 
12. Karasawa $\mathrm{T}$, Mihara $\mathrm{T}$, Kurazono H, Nair GB, Garg $\mathrm{S}$, Ramamurthy $\mathrm{T}$, et al. Distribution of the zot (zonula occludens toxin) gene among strains of Vibrio cholerae $\mathrm{O} 1$ and non-01. FEMS Microbiol lett. 1993; 106(2):143-5. PMID: 8454179

13. Baudry B, Fasano A, Ketley J, Kaper JB. Cloning of a gene (zot) encoding a new toxin produced by Vibrio cholerae. Infect Immun. 1992; 60(2):428-34. PMID: 1730472

14. Barzamini B, Moghbeli M, Arbab Soleimani N. Vibrio cholerae detection in water and wastewater by polymerase chain reaction assay. Int J Enteric Pathog. 2014; 2(4):1-4.

15. Mehrabadi JF, Morsali P, Nejad HR, Fooladi AA. Detection of toxigenic Vibrio cholerae with new multiplex PCR. J Infect Public Health. 2012; 5(3):263-7. PMID: 22632601

16. Herfehdoost GR, Kamali M, Javadi HR, Zolfagary D, Choopani A, Ghasemi B, et al. Rapid detection of Vibrio Cholerae by polymerase chain reaction based on nanotechnology method. J Appl Biotechnol Rep. 2014; 1(2): pp-59.

17. Bielawska-Drózd A, Mirski $\mathrm{T}$, Bartoszcze $\mathrm{M}$, Cieślik $\mathrm{P}$, Roszkowiak A, Michalski A. Development of real-time PCR assay for detection of Vibrio cholerae. Pol J Environ Stud. 2012; 21(2).
18. Fields PI, Popovic T, Wachsmuth K, Olsvik $\varnothing$. Use of polymerase chain reaction for detection of toxigenic Vibrio cholerae $\mathrm{O} 1$ strains from the Latin American cholera epidemic. $\mathrm{J}$ Clin Microbiol. 1992; 30(8):2118-21. PMID: 1500520

19. Koonin EV. The second cholera toxin, Zot, and its plasmidencoded and phage-encoded homologues constitute a group of putative ATPases with an altered purine NTP-binding motif. FEBS lett. 1992; 312(1):3-6. PMID: 1426234

20. Raja N, Shamsudin MN, Somarny W, Rosli R, Rahim RA, Radu S. Detection and molecular characterization of the zot gene in Vibrio cholerae and V. alginolyticus isolates. Southeast Asian J Trop Med Public Health. 2001; 32(1):100-4. PMID: 11485069

21. Fasano A, Uzzau S. Modulation of intestinal tight junctions by Zonula occludens toxin permits enteral administration of insulin and other macromolecules in an animal model. J Clin Invest. 1997; 99(6):1158. PMID: 9077522 